\title{
PERSEPSI TENTANG KELUARGA SAKINAH \\ (Studi Persepsi Para Pemenang Kontes Keluarga Sakinah Kota Balikpapan)
}

\author{
Abdurrohim \\ Sekolah Tinggi Ilmu Syariah (STIS) Hidayatullah Balikpapan \\ abiem.syam@gmail.com \\ Mutia Sakinah \\ Sekolah Tinggi Ilmu Syariah (STIS) Hidayatullah Balikpapan \\ mutia23@gmail.com
}

\begin{abstract}
Abstrak
Penelitian ini dilatarbelakangi dari realita yang terjadi di kalangan sebagian masyarakat yang menjadikan keluarga sebagai jembatan untuk meraih sebuah materi. Temuan data yang peneliti dapatkan dari hasil penelitian diketahui bahwa tiga dari lima responden setuju dengan keluarga sakinah terbentuk apabila bersumber pada al-Qur'an dalam membangun keluarga yang damai, bahagia, tentram, tenang dan sejahtera, dengan alasan telah disebutkan dalam al-Qur'an surah ar-Rum [30]: 21, hadits, dan banyak contoh yang bercerita tentang keluarga di zaman nabi dan para sahabat. Dua dari lima responden tidak setuju keluarga sakinah terbentuk apabila bersumber pada al-Qur'an dengan alasan yang membuat keluarga sakinah, bahagia, terdapat kesenangan, kasih sayang, ataupun rasa cinta, bukan dari syariat alQur'an atau hubungan rumah tangga itu sendiri melainkan terpenuhinya kebutuhan pokok dan terciptanya seorang anak sukses yang menghasilkan kekayaan dari rumah tangga yang biasa-biasa saja.
\end{abstract}

\section{Keyword: rumah tangga, damai, bahagia, cinta kasih}

\section{A. Pendahuluan}

Keluarga merupakan satuan terkecil dalam sistem sosial masyarakat yang tidak saja sebagai tentram lahir batin, dan kasih sayang tetapi juga sebagai perjanjian berat dan kokoh. ${ }^{1}$ Keluarga juga sebagai madrasah awal seorang anak yang akan menjadi benteng dan melindungi dari pengaruh-pengaruh negatif. ${ }^{2}$

Pendidikan keluarga perlu mendapatkan perhatian khusus, orang-orang di luar Islam berusaha memfokuskan diri untuk mewujudkan perluasan daerah jajahan mereka dengan cara merobohkan tatanan rumah tangga. ${ }^{3}$ Mereka tidak mendapatkan jalan lain untuk mewujudkan tujuannya selain menghancurkan generasi muda Islam. Maka mendidik anak sejak dini, tidak cukup untuk nasehat tapi harus dengan teladan yang mengajarkan dan menanamkan kejujuran, amanah, dan akhlak mulia lainnya. ${ }^{4}$ Kebanyakan derita rumah tangga adalah akibat tidak adanya saling memahami, atau tidak adanya terus terang salah satu pihak dengan tabiat dan kejiwaan orang-orang

${ }^{1}$ Hanifah, "Persepsi Masyarakat Pondok Pesantren Hidayatullah Balikpapan Terhadap Menikah Tanpa Pacaran," Skripsi, (Balikpapan: Perpustakaan STIS Hidayatullah, 2011), 1.

${ }^{2}$ Adil Fathi, Sudah Islamkah Keluarga Anda, (Solo: Darul Imam, 2007), 5.

${ }^{3}$ Ibid., 13.

${ }^{4}$ Hamim Thohari, “Rumahku Madrasahku," Suara Hidayatullah, Maret, 2007, 19. 
yang hidup di sekelilingnya. ${ }^{5}$

Maka syariat Islam memberikan metode yang akan mengantarkan umatnya ke arah kebahagiaan rumah tangga. Dalam metode itu, diletakkan aturan-aturan untuk menetapkan pilihan pasangan hidup sehingga kehidupan rumah tangga yang terbentuk adalah kehidupan suami istri yang saling menyayangi dan saling pengertian. Anak yang lahir sebagai buah hati perkawinan, juga tumbuh menjadi anak-anak yang cerdas berakhlak mulia serta saleh dan shalihah. ${ }^{6}$

Rumah tangga yang harmonis dan bahagia dapat dikatakan sebagai rumah tangga yang ideal. Akan tetapi untuk membangun sebuah keluarga tidaklah semulus yang dibayangkan.7 Berbagai cara yang ditempuh oleh pasangan suami istri dalam mewujudkan keluarga yang penuh kasih sayang dan cinta di dalamnya. Hanya saja mereka tidak menempatkan al-Qur'an sebagai satu-satunya pegangan hidup. Hal ini yang melatarbelakangi sehingga keluarga mudah retak.

Islam memandang rumah tangga dengan mengartikannya sebagai tempat ketenangan, keamanan, dan kesejahteraan. Islam juga memandang hubungan dan jalinan suami istri dengan hubungan cinta kasih dan sayang, serta menjalankan hubungan cinta kasih dan sayang ini di atas pilihan agar semuanya dapat berjalan dengan saling menyayangi dan mencintai satu sama lain. ${ }^{8}$

Rumah tangga adakalanya menjadi surga yang menyejukkan hati para penghuninya, namun juga bisa menjadi neraka yang menyesakkan. Ironisnya, tidak sedikit yang dijumpai rumah tangga kaum muslimin masa kini yang menjadi neraka membakar habis ketentraman dan kebahagiaan keluarga. Ini adalah sebuah malapetaka besar yang harus segera dicarikan solusinya. ${ }^{9}$

Berangkat dari hal tersebut, penelitian ini berusaha menemukan bagaimana konteks keluarga sakinah yang selama ini dimaknai bersifat abstrak dan baru pada tataran diskursif dan wacana teoritik semata. Yaitu dengan menggali persepsi tentang keluarga sakinah langsung dari para pemenang kontes keluarga sakinah yang diselenggarakan secara resmi oleh Pemerintah Daerah Kota Balikpapan. Dari situ dapat terlihat bagaimana praktik keluarga sakinah yang dilakukan oleh para pemenang kontes tersebut, karena mereka dinilai menjadi representasi dari konteks keluarga sakinah dalam ranah praksisnya. Dalam hal ini, peneliti berupaya menggali

2.

${ }^{5}$ Nabil Ibnu Muhammad, Smart Solving; Problematika Rumah Tangga, (Jakarta: Pustaka Al-Kautsar, 2007),

${ }^{6}$ Abdullah Nashih 'Ulwan, Tata Cara, h. 25.

${ }^{7}$ Syamsul Bahri, "Konsep Keluarga Sakinah Menurut M. Quraish Shihab”, (Yogyakarta: Universitas Islam Negeri Sunan Kalijaga Yogyakarta, 2009), 3.

${ }^{8}$ Sayyid Qutb, Tafsir Fi Zhilalil Qur'an, (Beirut: Darusy Syuruq, 1992), 307.

${ }^{9}$ Akbar Tahir, Persepsi Anggota Jama'ah Tabligh Tentang Keluarga Sakinah (Di Kelurahan Batu Ampar), (Skripsi: STIS Hidayatullah, 2013), 3. 
bagaimana praktik keluarga sakinah dan persepsi mereka tentang hal tersebut.

\section{B. Konsep Keluarga Sakinah}

\section{Definisi Keluarga Sakinah}

Keluarga berarti sanak saudara; kaum kerabat, ${ }^{10}$ diartikan dengan orangorang yang menjadi penghuni rumah, seisi rumah, ibu-bapak dan anakanaknya, serta satuan kekerabatan yang mendasar dalam masyarakat. ${ }^{11}$ Firman Allah swt dalam Q.S. at-Tahrim [66]: 6

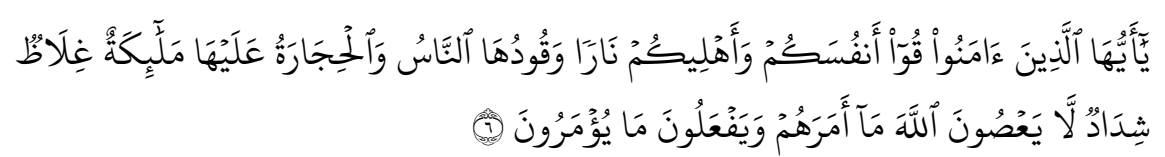

Keluarga adalah sebuah tatanan fitrah yang telah Allah tetapkan bagi jenis manusia. Bahkan para Rasul dan Nabi Allah pun juga menjalani hidup berkeluarga ${ }^{12}$ hal ini membuktikan bahwa keluarga adalah sebuah ikatan suci, mengandung hikmah dan memiliki misi Ilahiah secara abadi. ${ }^{13}$

Sedangkan kata sakinah dalam Kamus Ilmiah Populer berarti tentram, damai, ketenangan. Kata sakinah digunakan dalam al-Qur'an untuk menggambarkan kenyamanan keluarga. ${ }^{14}$ Istilah ini memiliki arti kata yang sama dengan sakanun yang berarti tempat tinggal, sedangkan dalam al-Qur'an diartikan sebagai tempat berlabuhnya setiap anggota keluarga dalam suasana yang nyaman dan tenang, sehingga menjadi tempat untuk tumbuhnya rasa cinta kasih (mawaddah warahmah) diantara sesama anggotanya. ${ }^{15}$

Sakinah dalam bahasa Arab memiliki pengertian aman, tentram, damai, dan tenang. Allah swt berfirman dalam Q.S ar-Rum [30]: 21

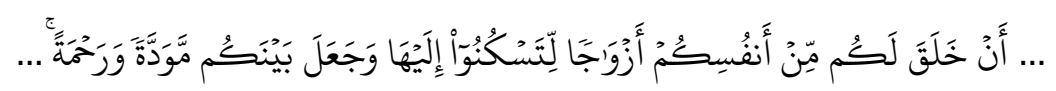

Keluarga sakinah merupakan hidup dalam suasana hati yang damai, tenang, ketentraman jiwa dan terbebasnya diri dari keinginan-keinginan yang dilarang. ${ }^{16}$ Keluarga sakinah juga keluarga yang semua anggotanya merasakan ketenangan, kedamaian, keamanan, ketentraman, perlindungan, kebahagiaan, keberkahan dan penghargaan. ${ }^{17}$ Maka mencapai rasa tersebut, pasangan suami istri menjalani bahtera keluarga sesuai dengan prinsip keimanan.

\footnotetext{
${ }^{10}$ Pusat Bahasa Departemen Pendidikan Nasional, Kamus Bahasa Indonesia, 676

11 Tim Prima Pena, Kamus Besar Bahasa Indonesia, (Gita Media Press), 414.

${ }_{12}$ Muhammad Thalib, 17 Karakteristik Pernikahan Islami, (Yogyakarta: Pro-U Media, 2008), 5.

${ }^{13}$ Ibid. 8

14 Masyi'ah Fauziyah, "Konsep Keluarga Sakinah Menurut Abdullah Said," Skripsi, (Balikpapan: Perpustakaan STIS Hidayatullah, 2011), 1.

${ }^{15}$ Akbar Tahir, Persepsi Anggota Jama'ah, 13.

${ }^{16}$ Mohammad Fauzul Adhim, Kupinang Engkau Dengan Hamdalah, (Yogyakarta: Mitra Pustaka, 2003), 175.

17 Ernawati, Cukupkah Cinta untuk Menikah?, (Yogyakarta: Checklist. 2018), 3.
} 
Kata sakinah tidak lepas pengucapannya dengan kata mawaddah dan warahmah. Kata mawaddah selalu terucap bersamaan dengan kata sakinah, karena sebelum membangun rumah tangga, langkah awal yang harus dimiliki adalah perasaan saling mencintai. ${ }^{18}$ Mawaddah merupakan perasaan cinta yang muncul terhadap pasangannya. ${ }^{19}$ Cinta adalah pengikat antara suami dan istri, sehingga keduanya saling memberi, bersama, memperhatikan, dan saling memenuhi kebutuhan lahir dan batin. ${ }^{20}$ Apabila suami istri bisa saling mencintai maka rumah tangga juga akan merasa lebih indah, dan harmonis.

Sedangkan warahmah merupakan kelanjutan dari mawaddah. Warahmah merupakan kasih sayang yang diberikan dengan rasa kepedulian, perhatian, dan pengertian terhadap satu sama lain. ${ }^{21}$ Kasih sayang inilah menjadi penghias paling indah antara suami istri. ${ }^{22}$

Oleh karena itu, keluarga yang dibangun dengan perasaan cinta dan kasih sayang maka semakin lama perasaan akan semakin besar rasa cinta dan kasih sayang dalam keluarga, sehingga terciptalah rumah tangga yang harmonis. ${ }^{23}$

\section{Keluarga Sakinah dalam Perspektif Al-Qur'an dan Sunnah (Hadis \)}

Kokohnya sebuah bangunan keluarga sangat berpengaruh terhadap kehidupan pribadi dan jamaah. ${ }^{24}$ Allah swt dengan kebijaksanaan-Nya, telah menjadikan keluarga sebagai tempat peraduan terhormat agar mendapatkan kenyamanan dan ketenangan di dalamnya. Allah swt berfirman dalam Q.S. arRum [30]: 21.

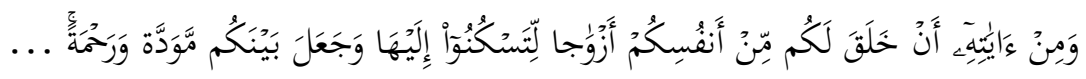

Allah 1 berfirman dalam Q.S al-Furqan [25]: 74.

$$
\text { V \& إِ... }
$$

Selanjutnya dalam hadis Rasulullah saw :

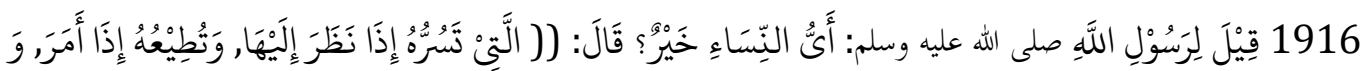

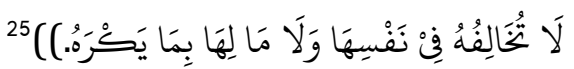

Artinya: Dari Abu Hurairah ra, ia berkata: "Rasulullah saw ditanya: Siapakah istri yang paling baik? Beliau menjawab: (Istri yang membuat hati suaminya senang apabila memandangnya. Jika suaminya memerintah, dia taat

18 Ummu Zahrani, Suamiku Surgaku, (Jakarta: Wahyu Qolbu, 2018), 4.

19 'Aidh bin Abdullah al-Qarni, Membangun Rumah dengan Takwa, (Jakarta: Magfirah Pustaka, 2006$), 8$.

${ }^{20}$ Sugiri Syarief, Menggapai Keluarga Berkualitas dan Sakinah, (Jakarta: Mitra Abadi Press, 2011), 12.

21 Ummu Zahrani, Suamiku Surgaku, 5.

22 Sugiri Syarief, Menggapai Keluarga Berkualitas dan Sakinah, 13. 2012), 58.

23 Muhammad Mutawalli Asy-Sya'rawi, Suami Istri Berkarakter Surgawi, (Jakarta: Pustaka Al-Kautsar,

${ }^{24}$ Muhammad Ahmad Isa, Rumah Tanggaku Paling Bahagia, (Solo: Wacana Ilmiah Press, 2009), 19.

${ }^{25}$ Muhammad Nashiruddin al-Albani, Silsilah al-Ahâdis| ash-Sahihah, (Riyadh: Maktabah al-Ma'arif, 1425 H/2004 M), 380. 
kepadanya. Dan tidak melawan suaminya dengan melakukan hal-hal yang dibencinya, baik terhadap dirinya dan hartanya.)) (H.R An-Nasa'I, al-Hakim, Ahmad)

Menerapkan al-Qur'an dalam keluarga maka Allah akan memberi keberkahan dalam membangun keluarga agar mencapai sakinah di dalamnya. ${ }^{26}$ Sabda Rasulullah saw terangkai dalam sebuah hadis \berikut :

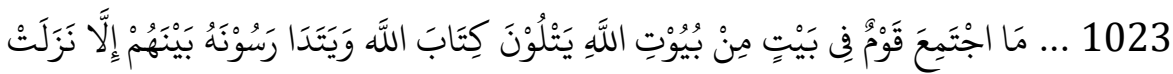

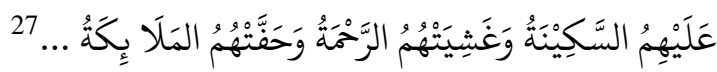

Artinya: Dari Abu Hurairah berkata Rasulullah : Tidak ada orang yang berkumpul dalam satu rumah Allah untuk membaca dan mempelajari al-Qur'an melainkan mereka akan memperoleh ketentraman, diliputi rahmat, dan dikelilingi oleh malaikat... (H.R. Muslim, Tirmiz \i, Ibnu Majah dan Abu Daud)

\section{Ciri-Ciri Keluarga Sakinah}

a. Terlaksananya Fungsi Keluarga

b. Melaksanakan Hak dan Kewajiban Suami maupun Istri

\section{Hak dan Kewajiban Suami Istri dalam Keluarga}

Islam hadir dengan penuh kasih sayang dan perhatian yang besar terhadap persoalan keluarga. Dalam kehidupan rumah tangga juga telah diatur hak dan kewajiban yang harus dipenuhi, sehingga dalam menjalani rumah tangga tidak mudah untuk mengambil keputusan sepihak. Adapun hak dan kewajiban suami dalam keluarga sebagai berikut :

\section{a. Suami}

1) Memimpin dengan cinta

2) Menjaga kepercayaan istri dan memahami sifatnya

3) Memberikan nafkah yang halal

4) Ketaatan istri dalam berhubungan (Jima')

b. Istri

1) Mahar

2) Mendapatkan nafkah

3) Taat kepada suami

4) Penyerahan diri

5) Ikut suami

${ }^{26}$ Ahsin. W Al-Hafidz, Bimbingan Praktis Menghafal Al-Qur'an, (Jakarta: Bumi Aksara, 2000), 35-40 
6) Menggembirakan hati suami dengan memperlihatkan wajah bahagia di depannya dan suara yang enak didengar olehnya. ${ }^{28}$

7) Tidak keluar rumah kecuali dengan izin suaminya ${ }^{29}$

8) Menjaga rahasia suami

9) Menjaga kehormatan dan harta suami

\section{Fungsi Keluarga Dalam Rumah Tangga}

Islam memandang setiap anggota keluarga sebagai pemimpin dalam kedudukannya masing-masing. Kepemimpinan yang dimaksud ialah bagaimana suami istri mampu bekerja sama dalam memimpin keluarganya. Islam mengajarkan prinsip adil berarti meletakkan fungsi-fungsi keluarga secara memadai. Fungsi keluarga berkaitan dengan satu dan yang lainnya. Pengabaian salah satu fungsi darinya, akan mengakibatkan keharmonisan keluarga menjadi berkurang.

\section{a. Fungsi Efektif dan Reproduksi}

Keluarga memberikan kasih sayang dan melahirkan keturunan.

\section{b. Fungsi Religius}

Keluarga memberikan pengalaman dan pendidikan keagamaan kepada anggota-anggotanya. Seperti kebiasaan-kebiasaan shalat, puasa, kejujuran, kedisiplinan, mengenal al Qur'an hendaknya ditanamkan sedini mungkin dalam keluarga.

\section{c. Fungsi Rekreatif}

Keluarga merupakan pusat rekreasi bagi anggotanya. Karenanya, suasana betah di rumah in home harus senantiasa diusahakan.

\section{d. Fungsi Protektif}

Keluarga melindungi anggota-anggotanya dari rasa takut, khawatir, ancaman fisik, ekonomis, dan psikosional. Artinya, keluarga merupakan tempat pemecahan masalah-masalah tersebut.

\section{e. Fungsi Edukatif}

Keluarga memberikan nilai-nilai pendidikan kepada anggotanya dan terutama anak-anak. Orang tua biasanya merupakan figur sentral dalam proses pendidikan dalam keluarga.

\section{f. Fungsi Sosial}

${ }^{28}$ Abdullah bin Jarullah Alu Jarullah, Rasail Al-afrah Linnisa Faqath, trans. Abu Umar Basyir (Jakarta: Pustaka At-Tazkia, 2006), 42.

${ }^{29}$ Muhammad Mutawalli Asy-Sya'rawi, Suami Istri Berkarakter Surgawi, (Jakarta: Pustaka Al-Kautsar, 2012), 357. 
Keluarga merupakan latihan proses sosialisasi nilai-nilai yang berlaku dalam masyarakat kepada para anggotanya, sekaligus keluarga juga memberikan prestise dan status kepada anggota-anggota keluarganya, dan fungsi lainnya.

\section{Menjaga Keutuhan Rumah Tangga}

Adapun Said Agil Husin al-Munawwar ${ }^{30}$, yang menyatakan bahwa simpulsimpul yang dapat mengantar atau menjadi prasyarat tegaknya keutuhan rumah tangga dalam keluarga adalah:

a. Dalam membangun sebuah keluarga harus ada mahabbah, mawaddah dan rahmah;

b. Hubungan suami isteri harus didasari oleh saling membutuhkan, seperti pakaian dan pemakainya (Hunna libasun lakum wa antum libasun lahunna);

c. Dalam pergaulan suami istri, mereka harus memperhatikan hal-hal yang secara sosial dianggap patut, tidak asal benar dan hak (wa'asyiruhinna bil ma'ruf), besarnya mahar, nafkah, cara bergaul dan sebagainya harus memperhatikan nilai-nilai ma'ruf;

d. Menjaga pilar-pilar keutuhan keluarga, yaitu:

1) Memiliki kecenderungan kepada agama

2) Mudah menghormati yang tua dan menyayangi yang muda

3) Sederhana dalam belanja

4) Santun dalam bergaul

5) Selalu introspeksi

6) Suami istri yang setia (shalih dan shalihah) kepada pasangannya

7) Anak-anak yang berbakti kepada orang tuanya

8) Lingkungan sosial yang sehat dan harmonis

9) Murah dan mudah rezekinya. ${ }^{31}$

\section{Faktor-Faktor Penentu Keutuhan Keluarga Sakinah}

a. Terjalinnya suatu komunikasi yang baik antar anggota keluarga

b. Kepercayaan

c. Kebersamaan

30 Said Agil Husin Al Munawwar, (lahir di Palembang, Sumatra Selatan, 26 Januari 1954; umur 65 tahun) beliau adalah seorang pengajar dan mantan Menteri Agama Indonesia. Ia menjabat sebagai Menteri Agama pada Kabinet Gotong Royong (2001-2004). Sekarang ia adalah dosen di UIN Syarif Hidayatullah, Jakarta.

31 Said Husin al-Munawwar, et.al, Agenda, 63. 

d. Bersyukur
e. Saling Mengalah Dalam Menyelesaikan Masalah
f. Memilih Lingkungan yang Baik

\section{Pendidikan Anak Dalam Islam}

\section{a. Metode Mendidik Anak Ala Nabi}

Anak-anak di hati Rasulullah saw sangatlah berarti. ${ }^{32}$ Seorang anak yang dekat dengan beliau akan mendapatkan sosok ayah yang penuh dengan kehangatan, kecintaan, guru terhormat, senyuman yang menyenangkan, dan senda gurau yang sangat menghibur namun penuh pendidikan. ${ }^{33}$

1) Menanamkan Ilmu Tauhid

2) Teladan yang Baik

3) Bersikap Adil dalam Memberi Terhadap Anak

4) Menunaikan Hak Anak

5) Mendoakan Kebaikan Anak

6) Menceritakan Kisah sebagai Teladan (Uswah)

7) Mendidik dengan Baik

8) Bersikap Lemah Lembut Terhadap Anak

\section{Gambaran Umum Lokasi Penelitian}

\section{Sejarah Kontes Keluarga Sakinah}

Kementerian Mahkamah Agung mengeluarkan fatwa Nomor 3 Tahun 1999 tentang Pembinaan Gerakan Keluarga Sakinah. Pada tahun ini belum berupa pemilihan Kontes Keluarga Sakinah namun hanya berupa pembentukan kontes tersebut.

Kontes Keluarga Sakinah resmi diselenggarakan pada tahun 2000 oleh Kementerian Agama Pusat di Jakarta. Program ini dilaksanakan sebagai salah satu bentuk perhatian pemerintah terhadap peran keluarga. Kontes Keluarga Sakinah Kota Balikpapan dibentuk dan diselenggarakan oleh pihak-pihak terkait seperti Kementerian Agama Kota Balikpapan, Kesejahteraan Rakyat Pemerintah Kota, DP3AKB, PKK Balikpapan dan Dharma Wanita Persatuan.

Kontes ini tidak hanya diselenggarakan oleh pihak pemerintah Kota Balikpapan, namun ke seluruh Indonesia. Kontes Keluarga Sakinah mempunyai beberapa persyaratan yang harus dilakukan oleh semua peserta kontes, yaitu

${ }^{32}$ Anas Ahmad Karzun, Anak Adalah Amanat, (Jakarta: Qisthi Press, 2006) 25.

33 'Aidh bin Abdullah al-Qarni, Membangun Rumah dengan Takwa, 86 
harus mencapai usia pernikahan 30 tahun ke atas, kesuksesan orang tua yang kurang mampu dalam mengantarkan anak-anak mereka menuju kesuksesan, serta besarnya peran orang tua dan anak dalam kehidupan masyarakat. Suksesnya seorang anak dilihat dari jenis pekerjaannya, tingkat pendidikannya, maupun tingkat keaktifannya di lingkungan masyarakat.

Namun pada tahun 2012 sampai 2017 panitia Kontes Keluarga Sakinah mengubah cara penilaian mereka yaitu tidak lagi harus dari orang tua yang tidak mampu ataupun tidak sukses melainkan tingginya tingkat pendidikan dan kesuksesan orang tua, karena semakin tinggi tingkat pendidikan dan kesuksesan orang tua akan semakin sulit mempertahankan prestasi anakanak. $^{34}$

\section{Visi Misi kontes Keluarga Sakinah}

Kontes Keluarga Sakinah memiliki visi yaitu Menjaga Ketahanan Keluarga Mencapai Keluarga Sakinah Wawaddah Warahmah. Misi Kontes Keluarga Sakinah adalah:

a. Menjaga keluarga agar tetap harmonis.

b. Menjadi teladan bagi masyarakat.

c. Mengukur ketahanan keluarga untuk dicontohkan ke calon pengantin. ${ }^{35}$

\section{Struktur Penilaian Kontes Keluarga Sakinah}

Kontes Keluarga Sakinah bukanlah seperti kontes pada umumnya. Kandidat Kontes Keluarga Sakinah dipilih oleh setiap Kepala Kelurahan yang dibantu tim penilai yaitu tim Kemenag, tim Kesra dan tim DP3AKB dengan syarat yang telah ditentukan oleh Kementerian Agama Pusat, bukan dari keluarga tersebut yang menawarkan diri sebagai peserta atau didaftarkan oleh RT/RW atau Kepala Desa mereka. Keluarga yang terpilih dari beberapa kelurahan tersebut akan disetor kepada kecamatan untuk diikutkan lomba antar kecamatan. Kemudian pemenang umum Kontes Keluarga Sakinah antar Kecamatan yang terpilih akan diikutkan lagi di Kementerian Agama tingkat Kota dan begitu seterusnya. ${ }^{36}$

\section{Sekilas Tentang Kota Balikpapan}

Kota Balikpapan merupakan salah satu kota yang menjadi pintu gerbang

${ }^{34}$ Masrivani, Ketua Kementerian Agama Kota Balikpapan, Wawancara Pribadi, 17 Februari 2019.

${ }^{35}$ Ibid.

${ }_{36}$ Masrivani, Ketua Kementerian Agama Kota Balikpapan, Wawancara Pribadi, 17 Februari 2019. 
Propinsi Kalimantan Timur, letaknya yang strategis menjadikannya sebagai tempat persinggahan warga Kalimantan Timur. Wujud implementasi warga Balikpapan dalam rangka memelihara, menjaga dan meningkatkan integritas Kota Balikpapan. ${ }^{37}$ Sebagaimana motto Kota Balikpapan "Ku Bangun, Ku Jaga, dan Ku Bela". Nama asli Balikpapan adalah Balikpapan atau Balikkappan yang merupakan logat Banjar. ${ }^{38}$ Balikpapan biasanya dikenal dengan Kota Minyak atau Benua Patra dan Bumi Manuntung yang berarti beruang madu.

Kota Balikpapan memiliki perekonomian terbesar di pulau Kalimantan, dengan total Rp.79,65 triliun pada tahun 2016. Sehingga biaya hidup di Balikpapan sangatlah mahal. Sedangkan dari sisi kependudukan, Balikpapan adalah kota terbesar kedua di Kalimantan Timur dengan total penduduk 636.012 jiwa di tahun 2017 setelah Samarinda. ${ }^{39}$

\section{Letak Geografis}

Kota Balikpapan mempunyai 6 kecamatan yaitu Balikpapan Timur, Balikpapan Selatan, Balikpapan Tengah, Balikpapan Utara, Balikpapan Barat, dan Balikpapan Kota.

Secara administrasi wilayah Kota Balikpapan memiliki batasan-batasan sebagai berikut ${ }^{40}$ :

- Luas Wilayah Kota Balikpapan : $\quad$ : $\quad 503,3 \mathrm{~km}^{2}$

- Jumlah Kecamatan : : 6

- Jumlah Kelurahan : $\quad 34$

- Batas-batas wilayah Kota Balikpapan :

a. Sebelah Utara : Berbatasan dengan Kabupaten Kutai Kartanegara

b. Sebelah Selatan : Berbatasan dengan Selat Makassar

c. Sebelah Timur : berbatasan dengan Selat Makassar

d. Sebelah Barat : Berbatasan dengan Kabupaten Penajam Paser

Utara

\section{Temuan Penelitian}

Setelah melakukan proses wawancara yang digunakan dalam bentuk "semi structured" dalam hal ini maka pertama pewawancara menanyakan

${ }^{37}$ Muslimah Saadah, "Persepsi Pegawai KUA Kecamatan Balikpapan Timur Tentang Hafalan Al-Quran Sebagai Mahar" (Skripsi, STIS Hidayatullah, 2017), 44.

${ }^{38}$ MS, Pegawai BPS Balikpapan, Wawancara Pribadi, 16 Februari 2018.

${ }^{39}$ Data dari BPS Kota Balikpapan.

${ }^{40}$ Badan Perencanaan Pembangunan Daerah, Penelitian dan Pengembangan Kota Balikpapan. 
urutan pertanyaan yang sudah ada, kemudian satu persatu di dalami dengan keterangan lebih lanjut. ${ }^{41}$ Dalam hal ini melakukan wawancara secara langsung dengan pemenang Kontes Keluarga Sakinah Kota Balikpapan. Dari wawancara tersebut dapat dikodifikasi dalam uraian persepsi dari masingmasing keluarga pemenang kontes keluarga sakinah yang berjumlah lima keluarga, sebagaimana uraian data berikut ini:

\begin{tabular}{|c|c|c|}
\hline NO & $\begin{array}{l}\text { Persepsi Pemenang Kontes Keluarga Sakinah } \\
\text { Kota Balikpapan Tentang Keluarga Sakinah }\end{array}$ & Keluarga \\
\hline 1. & $\begin{array}{l}\text { Rumah tangga sakinah mawaddah warahmah } \\
\text { dibangun atas landasan al-Qur'an dan sunnah. } \\
\text { Maka fungsi dan hak suami istri terjalin } \\
\text { sebagaimana mestinya, sehingga anak-anak } \\
\text { dapat merasakan kenyamanan, damai dan } \\
\text { tentram bersama dengan orangtua mereka. }\end{array}$ & $1,2,4$ \\
\hline 2. & $\begin{array}{l}\text { Faktor penentu yang dapat dikatakan keluarga } \\
\text { sakinah apabila terbentuk karena adanya } \\
\text { interaksi antara anggota keluarga yang saling } \\
\text { memberikan kasih sayang dan cinta dengan } \\
\text { ketakwaan, kehangatan, kepercayaan, sabar, dan } \\
\text { bersyukur. }\end{array}$ & $1,2,4$ \\
\hline 3. & $\begin{array}{l}\text { Mengartikan fungsi keluarga saling menghormati, } \\
\text { menghargai, berbagi, dan memberikan yang } \\
\text { terbaik untuk keluarga. }\end{array}$ & 1,2 \\
\hline 4. & $\begin{array}{l}\text { Rumah tangga yang sakinah mawaddah } \\
\text { warahmah hanya terbentuk apabila kebutuhan } \\
\text { primer tercapai. }\end{array}$ & 3 \\
\hline 5. & $\begin{array}{l}\text { Mempertahankan keutuhan rumah tangga } \\
\text { dengan sabar, mengalah, saling percaya, } \\
\text { mengingatkan kebaikan, dan saling menasehati } \\
\text { dalam kebenaran dan kesabaran. }\end{array}$ & $1,2,3,4$ \\
\hline 6. & Kesuksesan seorang anak karena adanya doa & $3,4,5$ \\
\hline
\end{tabular}

${ }^{41}$ Suharsimi Arikunto, Prosedur Penelitian, 270. 


\begin{tabular}{|c|l|c|}
\hline & $\begin{array}{l}\text { orang tua, mengarahkan cita-cita anak, dan } \\
\text { dorongan untuk maju. }\end{array}$ & \\
\hline 7. & $\begin{array}{l}\text { Penghambat suksesnya anak diakibatkan } \\
\text { makanan syubhat, kurangnya kasih sayang dari } \\
\text { orang tua, dan anak yang berasal dari keluarga } \\
\text { broken home. }\end{array}$ & $\mathbf{5}$ \\
\hline 8. & $\begin{array}{l}\text { Keluarga sakinah ditandai dengan keberhasilan } \\
\text { anak dalam mengumpulkan harta kekayaan, }\end{array}$ & $\mathbf{3 , 4 , 5}$ \\
\hline 9. & $\begin{array}{l}\text { Penyebab tingginya tingkat perceraian } \\
\text { diakibatkan keegoisan satu sama lain, ekonomi } \\
\text { yang tidak terpenuhi, serta emosi yang tidak } \\
\text { terkendali. }\end{array}$ & $\begin{array}{l}\text { Penyebab tingginya tingkat perceraian } \\
\text { diakibatkan tidak paham syariat dalam hukum } \\
\text { Islam }\end{array}$ \\
\hline 10. & $\mathbf{1 , 2 , 5}$ \\
\hline
\end{tabular}

Kesimpulan:

Dari penyajian matriks di atas, dapat disimpulkan bahwa ada sepuluh poin tentang gambaran persepsi pemenang Kontes Keluarga Sakinah, yang akan peneliti rangkum sebagai berikut:

1. Rumah tangga yang sakinah mawaddah warahmah dibangun atas landasan al-Qur'an dan sunnah sehingga dengan menerapkan landasan tersebut, rumah tangga yang saling memberikan kasih sayang dan cinta terhadap anggota keluarganya, karena fungsi keluarga telah terealisasikan sebagaimana mestinya. Hal ini sesuai yang dipaparkan oleh keluarga 1,2, dan 4.

2. Fungsi keluarga yang didefinisikan sebagai adanya interaksi saling menghormati, menghargai, saling berbagi, dan memberikan yang terbaik untuk keluarga.

Sebagaimana yang dipaparkan oleh keluarga 2 pada wawancara pribadi di kediaman beliau, yaitu:

"Fungsi keluarga sebenarnya yah itu, keluarga yang saling menghormati terhadapyang tua dan menyayangi yang muda, serta sebagai tempat saling berbagi antar sesama sehingga menciptakan kasih sayang dan cinta di antara kita karena kasih sayang itu sehingga di rumah ini tercipta rumah yang aman, damai, rukun, dan bahagia. Fungsi keluarga juga saling menaungi satu sama lain." 
Sama halnya dengan keluarga 4, yaitu:

"Perceraian akan terjadi apabila keegoisan kita dahulukan. Keluarga hadir bukan hanya sekedar menyempurnakan separuh dari agama, pernikahan juga bukan hanya mencari happy endingnya saja, tapi dibutuhkan cara kita untuk terus mempertahankannya. Sehingga dalam maksud mempertahankan itu, dibutuhkan sifat yang saling mengerti, perhatian terhadap anak-anak, saling mengisi, sabar, mengalah, saling percaya, dan saling mengingatkan serta menasehati dalam kebenaran dan kesabaran. Keluarga itu sendiri berfungsi untuk saling mengayomi antar anggotanya bukan saling mencari kesalahan dan saling memberi hukuman, namun bagaimana sebuah keluarga menciptakan suasana rumah menjadi keluarga yang qurrota 'ayun enak di pandang mata." hal ini juga dipaparkan oleh keluarga 1, 2, dan 3.

3. Keluarga 3 dan 5 mengartikan rumah tangga yang sakinah mawaddah warahmah hanya terbentuk apabila kebutuhan primer terpenuhi dan suksesnya mengantarkan anak pada tingkat keberhasilannya. Sebagaimana diuraikan berikut ini:

"Menurut saya keluarga sakinah itu apabila telah terpenuhinya makanan dalam rumah seperti beras dan lain-lain, karena hal ini yang paling dibutuhkan keluarga. Tanpa beras apa yang harus dimakan, apa yang harus diberikan kepada anak-anak untuk mengisi perutnya. Hal inikan akan menjadi masalah. Kemungkinan besar perkelahian. Kalau terus menerus berkelahi pasti rumah tidak akan tenang. Selain itu, Prestasi yang sangat membanggakan bagi kami adalah saat putra putri kami lulus dengan nilai yang sangat memuaskan yaitu cumlaude. Selain itu, setelah lulus dari perguruan tinggi mereka bekerja sesuai dengan bidang yang mereka miliki. Putra kami menjadi dosen di salah satu Universitas Negeri di Samarinda dan putri kami menjadi apoteker di salah satu perusahaan farmasi terbesar di Indonesia. Beginilah keluarga sakinah yang saya maksud, keluarga sakinah itu ditandai dengan keberhasilan anak dari orang tua yang tidak mampu."

Begitupun yang didefinisikan oleh keluarga 5,

"keluarga saya aman-aman aja, damai, bahagia, tentram, karena saya dan bapak berhasil mengarahkan anak-anak menuju sukses. Anak saya 5 yang alhamdulillah semuanya sukses, seperti anak saya yang mempunyai tambak yang mengekspor sampai ke beberapa negara tetangga dan sekitarnya." 


\section{E. Analisis Data}

\section{Analisis Persepsi Pemenang Kontes Keluarga Sakinah Kota Balikpapan Tentang Keluarga Sakinah}

Berdasarkan penelitian dan temuan data yang peneliti paparkan di atas, peneliti menemukan perbedaan persepsi pemenang Kontes Keluarga Sakinah Kota Balikpapan tentang keluarga sakinah. Melihat beberapa persepsi dari pemenang Kontes Keluarga Sakinah pada pengumpulan data yang peneliti dapatkan di lapangan bahwa ada tiga dari lima responden yang menyetujui keluarga sakinah terbentuk apabila bersumber pada al-Qur'an dan sunnah dalam membangun keluarga yang damai, bahagia, tentram, tenang dan sejahtera. Dalam hal ini sumber normatif dari Islam yaitu asas Al-Qur'an dan As-Sunnah sebagai landasan yang paling utama untuk membangun keluarga sakinah.

Selain itu ternyata ada responden yang tidak menyetujui bahwa keluarga sakinah musti berlandaskan al-Qur'an dan sunnah, seperti yang telah dicontohkan Rasulullah saw dengan argumentasi bahwa yang membuat keluarga sakinah, bahagia, terdapat kesenangan, kasih sayang, ataupun rasa cinta, bukan dari sekedar menerapkan al-Qur'an atau As-Sunnah. Di sisi lain, mereka juga berpendapat bahwa yang esensial dalam hubungan pernikahan dan rumah tangga itu adalah hadirnya anak-anak yang sukses secara materi dan pekerjaan, di mana kesuksesan materi dan pekerjaan itu bisa melampaui apa yang dicapai oleh kedua orang tuanya yang secara materi biasa-biasa saja. Meskipun terdapat suami istri, ataupun anak, apabila anaknya tidak sukses sama saja hanya membawa beban bagi keluarga. Rumah tangga akan kekurangan materi karena tanggungan anak maupun tanggungan keluarga yang terus meningkat sehingga mengakibatkan perpecahan. Oleh karena itu, kekurangan materi besar kemungkinan akan menyebabkan perceraian.

\section{Tinjauan Hukum Islam Terhadap Persepsi Keluarga Sakinah Menurut Para Pemenang Kontes Keluarga Sakinah Kota Balikpapan}

Data yang peneliti dapatkan dari penelitian ini yaitu data yang terdapat diwawancara langsung dengan beberapa orang suami istri yang pernah menjadi pemenang Kontes Keluarga Sakinah, peneliti juga mewawancarai beberapa orang lainnya untuk mendapatkan informasi yang lebih akurat. Dalam penelitian ini, peneliti memaparkan hasil wawancara dari 5 orang 
responden yang peneliti wawancarai secara mendalam, karena sebagian besar narasumber yang peneliti wawancarai mempunyai jawaban yang sama antara satu dan lainnya.

Pendapat responden ketiga dan kelima sebenarnya sah-sah saja karena dalam membangun sebuah keluarga memang dibutuhkan materi, dan semua orang pasti membutuhkan materi. Namun perlu diluruskan bahwa dalam segala aspek kehidupan, al-Qur'an dan sunnah sebagai pedoman umat Islam tidak bisa dipisahkan dari persoalan hidup apalagi dalam membangun sebuah keluarga. Karena dengan al-Qur'an dan sunnah akan melahirkan fungsi keluarga serta terealisasikannya hak dan kewajiban suami istri dalam mengantarkan sebuah keluarga menuju ketaatan kepada Allah, sehingga apabila fungsi, hak dan kewajiban suami istri telah terlaksanakan maka akan menciptakan kecintaan, ketenangan, kenyamanan, ketentraman. Oleh karenanya dari keluargalah generasi pelanjut lahir dan dari keluarga pula yang akan menentukan baik-buruknya generasi pelanjut tersebut. Sebagaimana dalil yang ada, disebutkan dalam firman Allah swt dalam Q.S. al-Rûm [30]: 21.

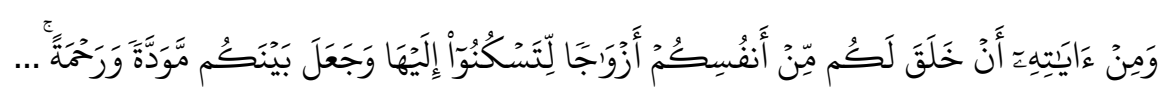

Sejalan dengan pendapat responden ketiga dan kelima, bahwa dalam al-Qur'an (an-Nahl ayat 97) terdapat kata حيّية طيّية di mana kata merupakan jamak dari kata thayyib, yang bermakna kehidupan yang nyaman dan sejahtera, sehingga tidak didera oleh rasa takut dan kesedihan. Dalam pengertian lain kata طيّية juga dikiaskan Raghib al-Isfahani, dengan ungkapan yang berbunyi: ما تستلذة الحواسو وما تستلذة النفس, yang bermakna suatu hal yang menyenangkan bagi panca indera dan menyenangkan pula bagi jiwa. Apabila ditarik dalam konteks berkeluarga, semestinya sebuah keluarga bertujuan untuk mendorong anak-anaknya untuk mencapai kualitas kehidupan yang lebih baik. Dalam pengertian kehidupan yang lebih nyaman dan sejahtera dari sebelumnya, di mana segala sesuatunya menyenangkan baik secara fisik maupun kejiwaan, sehingga tidak ada rasa takut dan kekhawatiran akan kesulitan dalam menjalani hidup. Penting harus dicatat bahwa konsep kenyamanan dan kesenangan disini tidak sama dengan konsep kesenangan (pleasure) yang dikembangkan oleh paham filsafat epikureanisme, yang memandang kesenangan secara materialistik.

Pencapaian kualitas kehidupan biasanya dibuktikan secara mudah dengan kepemilikan atas materi atau kekayaan. al-Qur'an menggunakan 
istilah ghina yang terulang dalam berbagai bentuknya sebanyak 73 kali, dan pada umumnya diterjemahkan dengan "kaya", serta dipahami secara keliru dalam arti "memiliki materi yang banyak". ${ }^{42}$ Karena dalam konsep Islam kemiskinan ruhani lebih berbahaya daripada kemiskinan materi, karena kemiskinan ruhani dapat menghambat manusia mencapai tujuan hidupnya yang hakiki. Walaupun demikian al-Qur'an memerintahkan manusia untuk berjuang meraih kehidupan duniawi. Salah satu indikatornya adalah seorang Muslim diajari agar berdoa dan berusaha meraih hasanah fi al-dunya dan hasanah fi al-akhirah. Allah Swt melalui al-Qur'an memerintahkan manusia untuk menjelajahi bumi yang terhampar untuk mencari rezekinya. Selain itu istilah yang digunakan untuk menunjukkan anugerah-Nya, adalah fadhl yang berarti "kelebihan". Jika demikian itu halnya, maka lanjut Quraish Shihab, pemilahan kekayaan dan kemiskinan pada dua sisi material dan spiritual, bukanlah berarti mengalihkan perjuangan kekayaan hanya semata-mata kekayaan spiritual, tetapi perjuangan tersebut adalah untuk mengingatkan manusia agar tidak larut dalam memperbanyak dan menumpuk harta benda, sebagaimana yang, antara lain diingatkan oleh sural al-Takatsur. ${ }^{43}$ Dengan demikian al-Qur'an telah memberikan proporsi dan garis demarkasi yang jelas bagi orang-orang yang ingin meningkatkan kualitas kehidupannya. Karenanya konsep hayatan thayyibah menjadi sasaran penting sebuah keluarga sakinah.

\section{F. Kesimpulan}

Melalui pembahasan pada bab-bab sebelumnya, mengenai persepsi pemenang Kontes Keluarga Sakinah Kota Balikpapan tentang keluarga sakinah ditinjau dari hukum Islam, maka peneliti akan mengemukakan beberapa kesimpulan sebagai berikut:

Hasil penelitian melalui wawancara yang telah diuraikan maka peneliti menyimpulkan bahwa persepsi pemenang Kontes Keluarga Sakinah Kota Balikpapan secara umum menyetujui dalam kesepakatan dikatakan sebagai keluarga sakinah apabila suami, istri, anak-anak, menantu, bahkan cucu, saling memberikan ketenangan, kebahagiaan, cinta dan kasih sayang, ketentraman dan fungsional satu sama lain, serta berlandaskan al-Qur'an dan sunnah dalam membina keluarga, seperti yang telah dicontohkan Rasulullah SAW dahulu saat membina dan membimbing

${ }^{42}$ M. Quraish Shihab, Secercah Cahaya Ilahi: Hidup Bersama al-Qur'an, (Bandung: Mizan, 2000), hlm. 162. 
keluarga beliau. Adapun yang tidak menyetujui berpendapat bahwa keluarga sakinah di dapatkan dari kesuksesan anak dalam mengumpulkan harta kekayaan., karena di zaman Rasulullah tidak ada harta sehingga kebahagiaan hanya di nilai dari kesenangan dan ketenangan.

Persepsi pemenang Kontes keluarga Sakinah tentang keluarga sakinah jika ditinjau dari hukum Islam sah-sah saja dengan lebih mengutamakan harta dari alQur'an dan sunnah. Namun perlu diluruskan bahwa al-Qur'an dan sunnah tidak bisa lepas dalam kehidupan manusia karena sebagai pedoman umat Islam. Akibatnya apabila al-Qur'an dipisahkan dari kehidupan rumah tangga, maka banyak kewajibankewajiban dalam keluarga akan terabaikan sehingga fungsi keluarga tidak tercapai sebagaimana mestinya. 


\section{DAFTAR PUSTAKA}

Abdullah Nashih 'Ulwan. Tata Cara Meminang Dalam Islam. Jakarta: Qisthi Press, 2006.

Adhim, Mohammad Fauzul. Kupinang Engkau Dengan Hamdalah. Yogyakarta: Mitra Pustaka, 2003.

Al-Halili, Salim Bin ‘Ied. Syarah Riyadus Salihin. Jakarta: PT. Pustaka Imam Asy-Syafi'i, 2006.

Al-Qarni, 'Aidh bin Abdullah. Membangun Rumah dengan Takwa. Jakarta: Magfirah Pustaka, 2006.

Alu Jarullah, Abdullah bin Jarullah. Rasail Al-afrah Linnisa Faqath, trans. Abu Umar Basyir (Jakarta: Pustaka At-Tazkia, 2006.

Asy-Sya'rawi, Muhammad Mutawalli. Suami Istri Berkarakter Surgawi. Jakarta: Pustaka Al-Kautsar, 2012.

Bahri, Syamsul. "Konsep Keluarga Sakinah Menurut M. Quraish Shihab.” Skripsi, Universitas Islam Negeri Sunan Kalijaga Yogyakarta, 2009.

Ernawati, Cukupkah Cinta untuk Menikah ?. Yogyakarta: Checklist. 2018.

Fathi, Adil. Sudah Islamkah Keluarga Anda. Solo: Darul Imam, 2007.

Hamim, Thohari. "Rumahku Madrasahku," Suara Hidayatullah. Maret, 2007.

Hanifah. "Persepsi Masyarakat Pondok Pesantren Hidayatullah Balikpapan Terhadap Menikah Tanpa Pacaran.” Skripsi, STIS Hidayatullah, 2011.

Isa, Muhammad Ahmad. Rumah Tanggaku Paling Bahagia. Solo: Wacana Ilmiah Press, 2009.

Karzun, Anas Ahmad. Anak Adalah Amanat. Jakarta: Qisthi Press, 2006.

Masrivani, Ketua Kementerian Agama Kota Balikpapan, Wawancara Pribadi, 17 Februari 2019.

MS, Pegawai BPS Balikpapan, Wawancara Pribadi, 16 Februari 2018.

Muhammad Thalib, 17 Karakteristik Pernikahan Islami, (Yogyakarta: Pro-U Media, 2008), 5.

Muhammad, Nabil Ibnu. Smart Solving; Problematika Rumah Tangga. Jakarta: Pustaka Al-Kautsar, 2007.

Pusat Bahasa Departemen Pendidikan Nasional. Kamus Besar Bahasa Indonesia. Jakarta: Pusat Bahasa, 2008.

Qutb, Sayyid. Tafsir Fi Zhilalil Qur'an. Beirut: Darusy Syuruq, 1992.

Saadah, Muslimah. "Persepsi Pegawai KUA Kecamatan Balikpapan Timur Tentang Hafalan Al-Quran Sebagai Mahar". (Skripsi, STIS Hidayatullah, 2017. 
Syarief, Sugiri. Menggapai Keluarga Berkualitas dan Sakinah. Jakarta: Mitra Abadi Press, 2011.

Tahir, Akbar, "Persepsi Anggota Jama'ah Tabligh Tentang Keluarga Sakinah (Di Kelurahan Batu Ampar)." Skripsi, STIS Hidayatullah, 2013.

Tim Prima Pena. Kamus Besar Bahasa Indonesia. Gita Media Press.

Zahrani, Ummu. Suamiku Surgaku,. Jakarta: Wahyu Qolbu, 2018. 